\title{
THE POSSIBILITIES OF REDUCING THE OPERATIONAL LOAD OF HOISTING MECHANISMS IN CASE OF DYNAMIC HOISTING
}

\section{MOŻLIWOŚCI ZMNIEJSZENIA OBCIĄŻEŃ EKSPLOATACYJNYCH MECHANIZMÓW DŹWIGNIC DLA PRZYPADKU DYNAMICZNEGO PODNOSZENIA ŁADUNKU*}

\begin{abstract}
The simulation and experimental tests of hoisting mechanism in case of dynamic lifting the payload with clearance of ropes are presented in this paper. The minimization methods of the overloading of hoisting mechanisms were described. Basing on simulation tests the method that assured minimization of dynamics overloading with a few dozen to a few percent was introduced. It was determined the impact of the level of sensitivity of forces in ropes measurement on minimization of the overloading. The examples of the method implementation used for the real hoisting mechanism were shown.
\end{abstract}

Keywords: hoisting winch, overloads, control.

\begin{abstract}
W artykule przedstawiono badania symulacyjne i eksperymentalne mechanizmu podnoszenia dla przypadku podrywania tadunku. Opisane zostały metody zmniejszania przeciażeń uktadu napędowego mechanizmów podnoszenia. Wskazano w oparciu o badania symulacyjne metodę zapewniająca minimalizację przeciażeń dynamicznych w czasie podrywania ładunku z kilkudziesięciu do kilku procent. Określony zostat wpływ poziomu czułości pomiaru sit w linach na minimalizację przeciążeń. Zaprezentowano przykłady zastosowań metody na rzeczywistej wciagarce bębnowej.
\end{abstract}

Stowa kluczowe: wciagarka, przeciążenia, sterowanie.

\section{Introduction}

Besides the reliability, main requirements for vertical transport are positioning, use of power and reducing of the dynamic loads. For the hoisting mechanism the worst case in terms of appearing overloads is when the lifting operation starts when ropes have clearance. This case is called a jerk of a payload. The case when the ropes clearance is so big that when the ropes tensing began, the angular speed of the drum is near the reference speed. The research of overloads in drive systems usually comes up in the context of their impact on the steel structures of devices. For example in papers [1], [7] and [11] the tests of load dynamics of steel structures of the overhead cranes during payloads lifting were described. In [14], authors presented the model of the hoisting mechanism, where the stiffness of the girder has been taken into account. In these articles there were presented the studies of the behavior of the cranes structures under dynamic loads using FEM method. In [15] the influence of the hoisting mechanism operation on the crane structure was presented. There were presented waveforms of forces in ropes for different methods of increasing the drum speed from linear to inertial with various time constants. The problem of the crane structures load by vertical dynamic forces appeared also in [4] and [16], where the systems with moving mass were described. Reduction of dynamic overloads made by hoisting mechanisms operation provides measurable exploitation benefits, such as: minimization of the structure overload or reducing the power consumption. There were presented also methods of reduction of the steel structure loads by using dampers, eg. in [9]. Research of overloads of hoisting winches for varies cases of lifting were described in [12]. The authors of [10] worked on modeling of hoisting mechanisms equipped with different drive systems.

The authors of [3] paid attention to necessity of consideration the various types of the loads of mechanisms caused eg. by the control methods and the limited scope of application of the cranes automa- tion. The conclusion is that the control systems which reduce a temporary load should be used both for automatic and manual control of hoisting winches.

In [5] authors pointed the specificity of drives of hoisting winches, which: "are distinguished with respect of their requirements, regarding the control of speed and position and the acceleration phase carried with an active load". The usage of modern drive systems based on frequency inverters, allows meet these requirements.

As can be seen the problem of overloads of hoisting mechanisms appears mainly in context of dynamic loads of supporting structures or research of dynamics of hoisting mechanisms. In our opinion, which is based on reading the available literature, the issues of reduce dynamic loads is presented only in context described above.

In the paper there is presented a drive system, which allows reduce dynamic overloads during lifting of a payload. Especially when a payload is jerk, the overloads are high. It was assumed that the proper control of a duty cycle allows reduce appearing overloads. Developed by authors, the method of minimization of dynamic overloads during lifting of the payload using continuous measure of the payload mass and constant power controller for hoisting mechanism are presented as well. Basing on developed models and both simulation and experimental tests, the results of minimization methods operation are shown.

\section{The model of the hoisting winch}

To examine the possibilities of minimization of the overload of the hoisting winch drive system, two experimentally verified models were used. The model, which inter alia was described in [2], of mechanical system of the hoisting winch and the model of the system: inverter - motor stator which was presented in [8].

$\overline{(*)}$ Tekst artykułu w polskiej wersji językowej dostępny w elektronicznym wydaniu kwartalnika na stronie www.ein.org.pl 


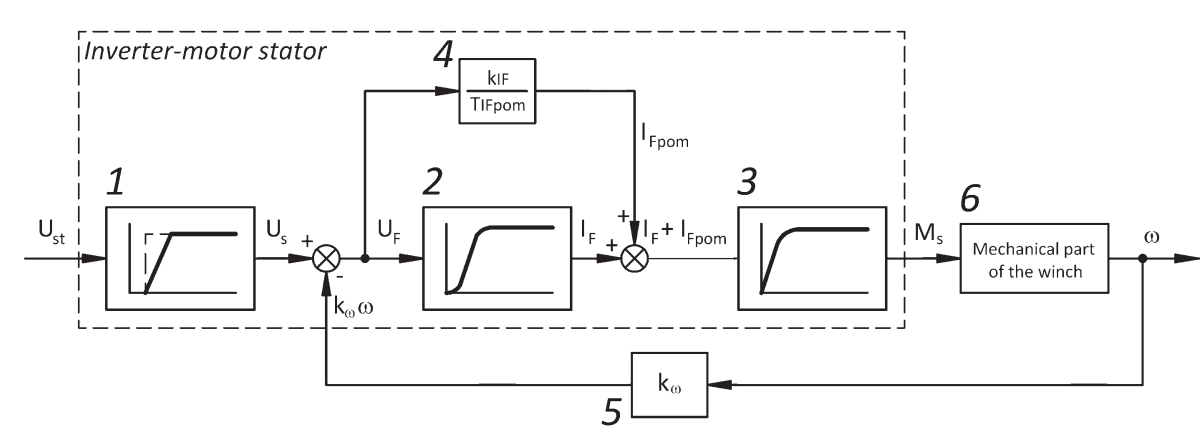

$\mathrm{I}_{\mathrm{F}} \quad$ - stator current,

$\mathrm{I}_{\mathrm{F}}, \quad$ - auxiliary variable - current

$\mathrm{I}_{\mathrm{Fpom}}$ - auxiliary stator current,

$\mathrm{M}_{\mathrm{s}} \quad$ - torque on the motor stator,

$\mathrm{U}_{\mathrm{s}} \quad$ - control voltage

For the system described above, the control signal $U_{\text {st }}$ proportional to the reference speed of the motor was the input signal. As the output signals an angular speed of the motor $\omega$ and a torque $\mathrm{M}_{\mathrm{S}}$ were assumed. To determine a speed $\omega$, the mechanical part of the hoisting winch should be modeled. Figure 2 presents the model of mechanical part of the hoisting winch and schema of the drive system.

The model of system: inverter - motor stator, which is presented on figure 1 , was described using typical equations of dynamic elements. Elements 2, 3 and 4 are described respectively as inertial element second-order or first-order and as integral element. The integrating adjuster 1 was modeled as well. The task of this element is to limit the speed of increasing of dynamic values of the signal $U_{s}$ as response on rapid change of the input signal $\mathrm{U}_{\mathrm{st}}$. The element 5 which converts motor speed to a voltage signal presents the existence of inner feedback of the speed $\omega_{\mathrm{s}}$ inside the inverter.

Description in the space of state variables of the system presented on figure 1 is as follows:

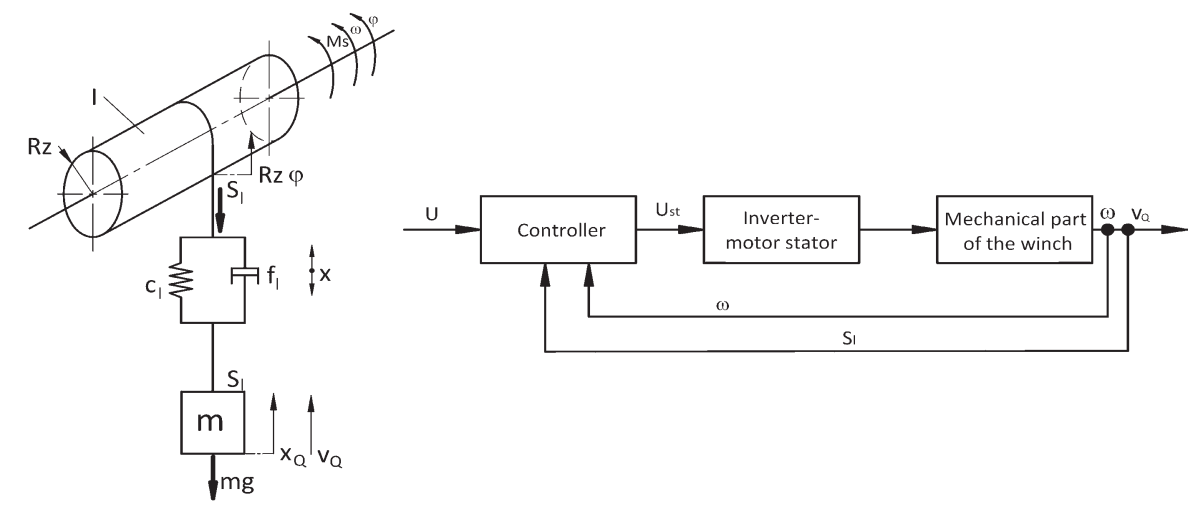

Fig. 2. The model of mechanical part of the hoisting winch and schema of the drive system.

$$
\frac{\mathrm{dUs}}{\mathrm{dt}}=\frac{1}{\mathrm{~T}_{\mathrm{C}}} \times \mathrm{U}_{\mathrm{SZ}}
$$

- element 1

The model is described in the space of state variables using between others rules presented in [13]. The mathematical model of the mechanical part of the hoisting winch in space of state variables is as follows:

$$
\begin{aligned}
& \frac{\mathrm{dI}_{\mathrm{F}}{ }^{\prime}}{\mathrm{dt}}-\frac{\mathrm{k}_{\mathrm{IF}} \times \mathrm{k}_{\mathrm{wzm}}}{\mathrm{T}_{\mathrm{F} 1}^{2}} \times\left(\mathrm{U}_{\mathrm{S}}-\mathrm{k}_{\mathrm{E}} \times \omega\right)-\frac{\mathrm{T}_{\mathrm{F} 2}^{\mathrm{F}}}{\mathrm{T}_{\mathrm{F} 1}^{2}} \times \mathrm{I}_{\mathrm{F}}{ }^{\prime}-\frac{1}{\mathrm{~T}_{\mathrm{F} 1}^{2}} \times \mathrm{I}_{\mathrm{F}} \\
& \frac{\mathrm{dI}_{\mathrm{F}}}{\mathrm{dt}}=\mathrm{I}_{\mathrm{F}}{ }^{\prime}
\end{aligned}
$$

$$
\begin{gathered}
\frac{\mathrm{dM}_{\mathrm{s}}}{\mathrm{dt}}=\frac{\mathrm{k}_{\mathrm{Ms}}}{\mathrm{T}_{\mathrm{Ms}}} \times\left(\mathrm{I}_{\mathrm{F}}+\mathrm{I}_{\mathrm{Fpom}}\right)-\frac{1}{\mathrm{~T}_{\mathrm{Ms}}} \times \mathrm{M}_{\mathrm{s}} \\
\frac{\mathrm{dI}_{\mathrm{Fpom}}}{\mathrm{dt}}=\frac{\mathrm{k}_{\mathrm{IF}}}{\mathrm{T}_{\mathrm{IFpom}}} \times\left(\mathrm{U}_{\mathrm{s}}-\mathrm{k}_{\omega} \times \omega\right)
\end{gathered}
$$$$
\text { - element } 3
$$

The following markings were assumed in equations:

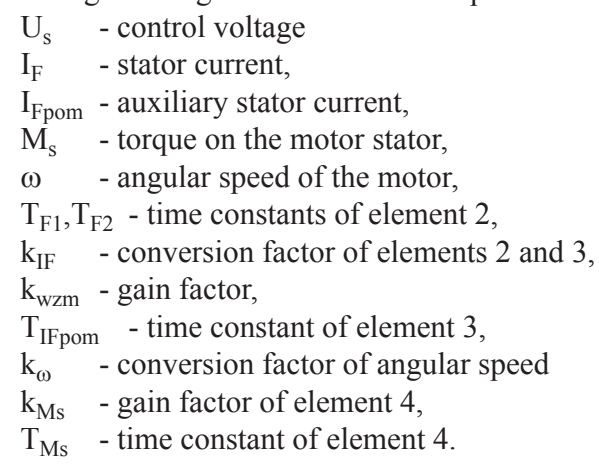

where:

$$
\begin{aligned}
& \frac{\mathrm{d} \omega}{\mathrm{dt}}=\frac{1}{\mathrm{I}_{\mathrm{z}}} \times \mathrm{M}_{\mathrm{s}}-\frac{\mathrm{c}_{1}}{\mathrm{I}_{\mathrm{z}}} \times \mathrm{x}-\frac{\mathrm{R}_{\mathrm{z}} \times \mathrm{f}_{1}}{\mathrm{I}_{\mathrm{z}}} \times \omega+\frac{\mathrm{f}_{1}}{\mathrm{I}_{\mathrm{z}}} \times \mathrm{v}_{\mathrm{Q}} \\
& \frac{\mathrm{dx}}{\mathrm{dt}}=\mathrm{R}_{\mathrm{z}} \times \omega+\mathrm{v}_{\mathrm{Q}} \\
& \frac{\mathrm{dv} \mathrm{Q}}{\mathrm{dt}}=\frac{\mathrm{c}_{1}}{\mathrm{~m}} \times \mathrm{x}-\frac{\mathrm{R}_{\mathrm{z}} \times \mathrm{f}_{1}}{\mathrm{~m}} \times \omega+\frac{\mathrm{f}_{1}}{\mathrm{~m}} \times \mathrm{v}_{\mathrm{Q}}-\mathrm{g}
\end{aligned}
$$

$$
\begin{array}{ll}
\mathrm{x} & \text { - elongation of a rope system } \\
\mathrm{I}_{z} & \text { - effective moment of inertia of rotational parts of the } \\
\mathrm{m} & \text { hoisting winch } \\
\mathrm{R}_{\mathrm{z}} & \text { - mass of the payload } \\
\mathrm{c}_{1} & \text { - effective radius } \\
\mathrm{f}_{1} & \text { - damping ratio } \\
\mathrm{v}_{Q} & \text { - speed of the payload }
\end{array}
$$

The following state variables were established:

$$
\begin{array}{ll}
\mathrm{x} & \text { - elongation of a rope system } \\
\mathrm{v}_{\mathrm{Q}} & \text { - speed of the payload } \\
\omega & \text { - angular speed of the motor, }
\end{array}
$$

The following state variables were specified: 
Finally the description of the mechanical part of the hoisting winch, which includes drive system fed by the inverter was obtained. The following output variables were established:

$\begin{array}{ll}\omega & \text { - angular speed of the motor } \\ \mathrm{V}_{\mathrm{Q}} & \text { - speed of the payload } \\ \mathrm{X} & \text { - elongation of a rope system } \\ \mathrm{M}_{\mathrm{S}} & \text { - torque on the motor stator } \\ \mathrm{S}_{1} & \text { - force in ropes }\end{array}$

The input for the system was voltage signal $U$ which is inverter control signal and it is proportional to reference angular speed of the motor.

The solving of the model allowed to carry some simulation tests to determine dynamic behavior for the different cases of hoisting winch operation and varies control systems.

\section{The methods of overload reduction during lifting}

In case of the jerk of a payload - which gives the biggest overloads in drive system, a few methods and control systems allowing minimize overloads were checked.

Mostly used method of hoisting mechanism control consist in linear acceleration and deceleration (linear change of the speed during acceleration and deceleration phases), independently on initial state of the mechanism. In figure 3 are shown exemplary wavecharts of speed $\mathrm{v}_{\mathrm{b}}$, force in ropes $\mathrm{S}_{1}$ and input signal $U$ during the jerk of a payload with linear changes of input signal. The jerk of a payload occurs when after connection ropes with the payload, the clearance of the ropes remains. So, the start-up of the motor is practically without load. The steady speed of the motor (and drum) is reached when ropes still are with clearance. After deleting the clearance, the rope began to be tension, as it is shown in figure 3, seen as the rapid growth of the force in ropes. Lifting of the payload starts when force $S_{1}$ exceed the value of border force equal to the payload weight. The overload in presented

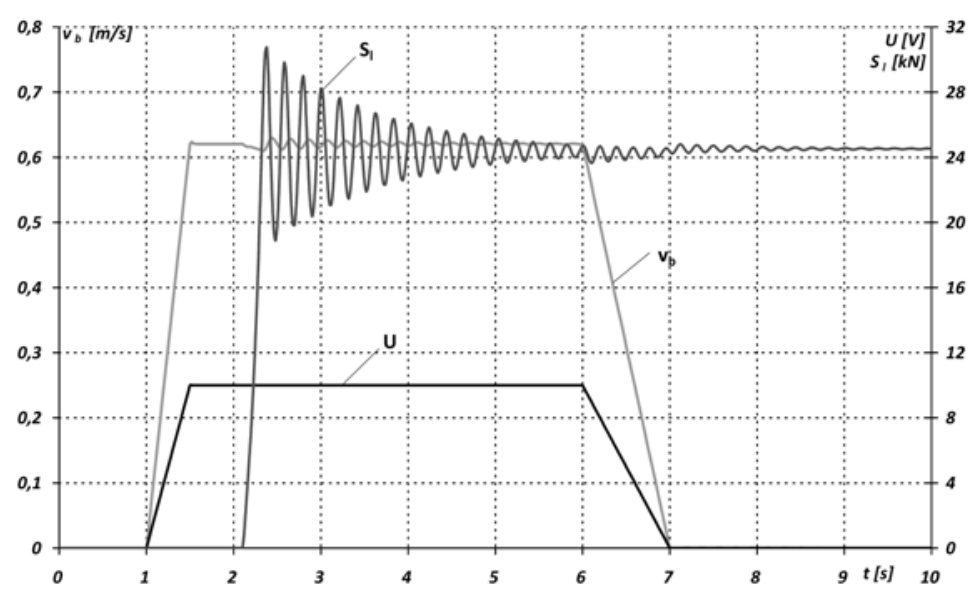

Fig. 3. Jerk of the payload with trapezoidal input

case reached $25 \%$ above the steady value.

This case concerned the payload with mass 2,5 tons, which was lifting with speed about $0.63 \mathrm{~m} / \mathrm{s}$.

The reduction this kind of overloads could be done eg. by increasing the acceleration time, but it is not always possible and desirable because of the longer time of the duty cycle.

One of the methods that allows reduce dynamics overloads is the start-up with preliminary speed, what was presented inter alia in [6]. An exemplary algorithm cover the following phases:

- preliminary movement with low speed (eg. $10 \%$ of steady speed) during defined time

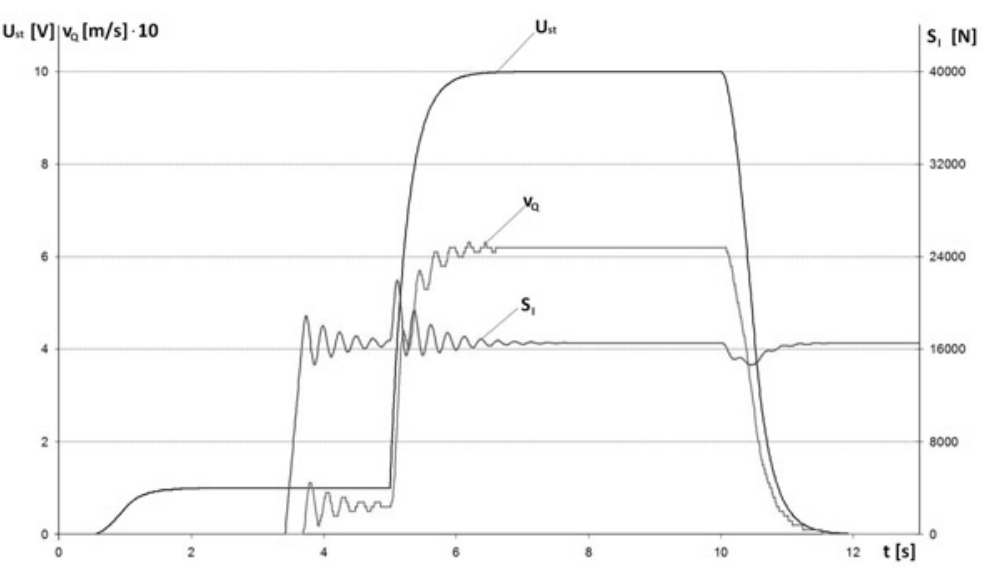

Fig. 4. Lifting the payload with preliminary speed

- measurement of the force in ropes

- movement with maximum allowed speed using constant power regulator

Figure 4 illustrates the operation of this system. The advantage of this method is the possibility of using constant power regulator, which increases efficiency of the machine and enables full power usage. The disadvantage is the necessity of deleting the clearance during preliminary movement. If not, the payload is still jerk. In addition, the constant power regulator will not operate properly because of wrong data about load. In cases of small payloads, the preliminary movement is redundant, because the times of the duty cycles are getting longer.

Disadvantages mentioned above could be removed by using the other algorithm of control, which is basing on following assumptions:

1. Lifting a payload with maximum allowed speed with continuous measurement of a force in ropes,

2. At the moment of the detection of the load follows:

a) stopping the lifting,

b) after establishing the conditions, the measurement of forces in ropes,

c) next, starting the lifting with maximum allowed speed.

It was important to define the proper level of force measurement sensitivity which is important because of reduction of overloads. The comparison of various settings of the force sensor are presented in figure 5, where the wavecharts of forces in ropes for different sensitivity thresholds, the levels of maximum forces and also the input functions are shown.

Application of a lower threshold of force sensor allows to reduce the dynamic overloads in ropes system. The comparison of the maximum overloads for cases presented on figure 5 , which are calculated as quotient of a maximum and steady force, were as follows:

\begin{tabular}{|c|c|c|c|c|}
\hline $\begin{array}{c}\text { Sensor } \\
\text { threshold }\end{array}$ & $\begin{array}{c}\text { Without } \\
\text { sensor }\end{array}$ & $10000 \mathrm{~N}$ & $5000 \mathrm{~N}$ & $500 \mathrm{~N}$ \\
\hline Overloads & 1,252 & 1,217 & 1,161 & 1,097 \\
\hline
\end{tabular}

The reduction of overload can reach over a dozen percent of steady value.

The implementation of this algorithm could be difficult. Figure 6 shows case when the second phase of the cycle starts with ropes clearance. This gives the effect of next payload jerk and consequently the absence of the overload reduction. It is important to assure the tensioning of the ropes before second phase starts. 


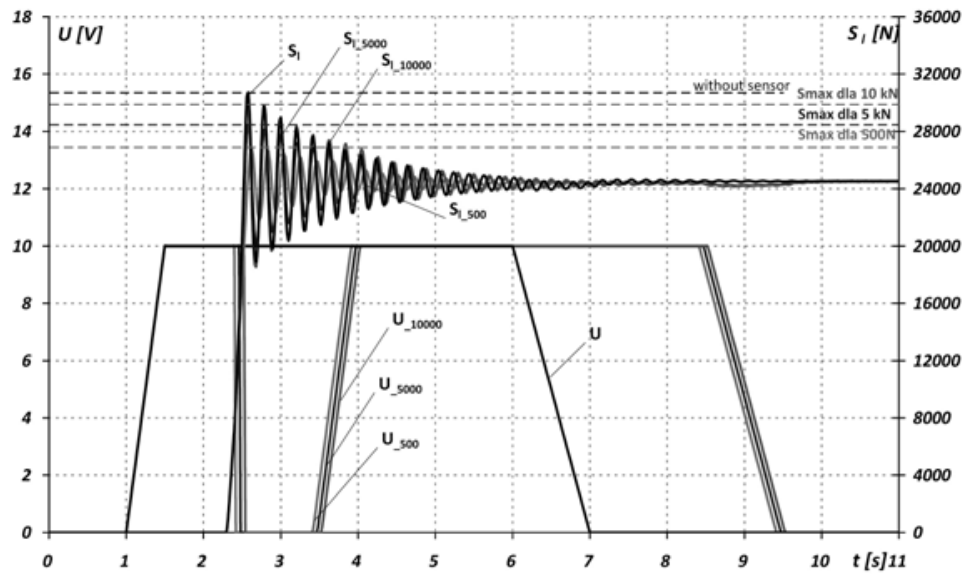

Fig. 5. The comparison of forces in ropes for different sensor thresholds

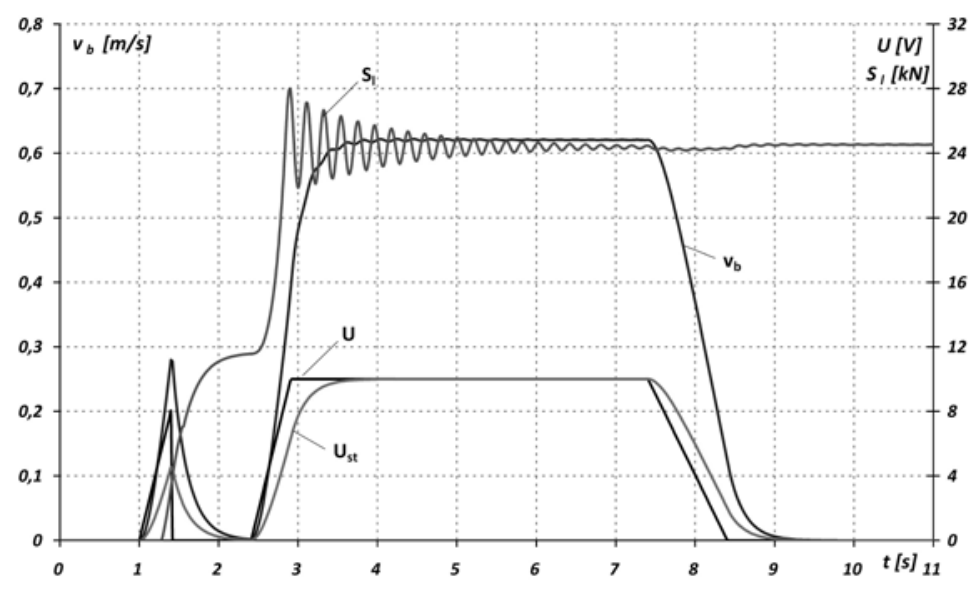

Fig. 6. Wavechart of force in ropes in case of low clearance

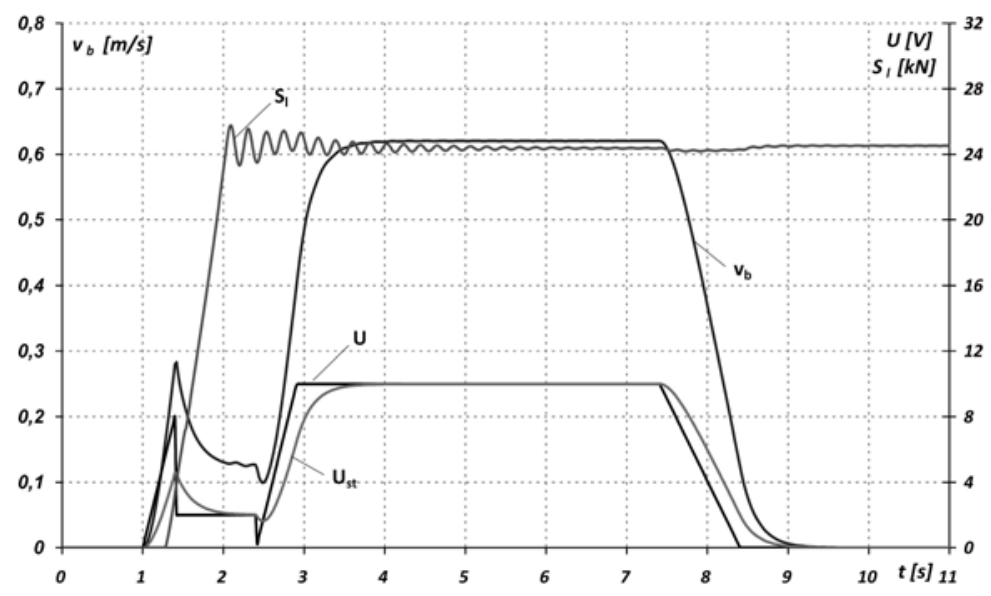

Fig. 7. Wavechart of force in ropes in case of reduced intermediate speed

One of solutions is replacing the stop of a movement by reduction of a speed. The speed should be at the low level which assures the tensioning of the ropes. A time of the movement depends on characteristic of the operation of the hoisting winch - speed and methods of payload fixing. This case is presented in figure 7. The overload is reduced to about $5 \%$ in contrary to $14 \%$ in case shown in figure 6 .

The results of simulation tests carried on the model of hoisting winch, allowed to check the effectiveness of described method on real device.

\section{The test stand}

Good results of simulation tests of the system reducing overloads, allowed the experimental tests which should confirm good operation of the system installed on real winch. The assumptions were made that the ropes were clearanced, the mass was defined and was standing on the ground. The trapezoidal input signal using varies times of acceleration (including step function) were also assumed. The tests were carried both with operating and switched off system of overload reduction.

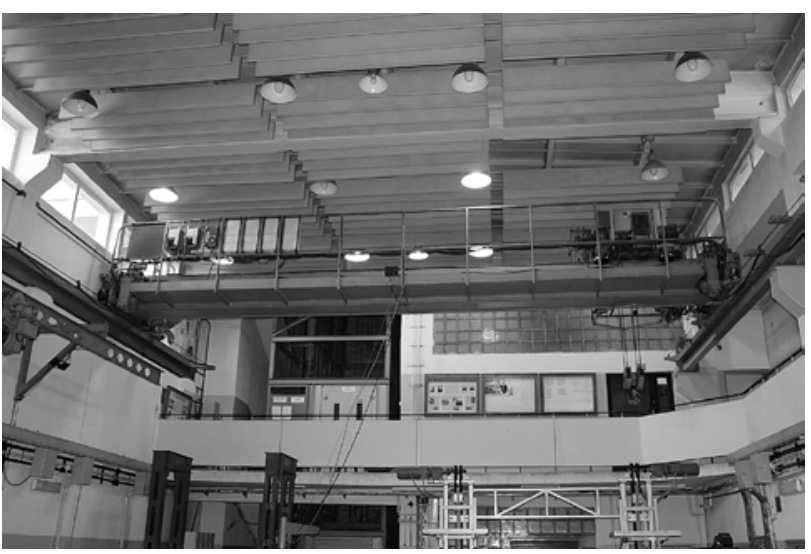

Fig. 8. The laboratory overhead crane

The test stand consisted of hoisting winch installed on real overhead crane equipped with necessary control and measurement systems. Overhead crane was installed in Laboratory of Division of Working Machined, Drives and Control in Lodz University of Technology. The main parameters of the crane were as follows: capacity $50 \mathrm{kN}$, span $10 \mathrm{~m}$ and lifting height $6 \mathrm{~m}$. Described overhead crane is presented in figure 8 .

All the mechanisms were equipped with the system: frequency inverter - asynchronous motor. Each inverter was managed by microprocessor controller which performed all the required functions of the control of the mechanism. In addition, the logic functions of the mechanisms such as control of mechanical brakes or limit switches were also managed by the controllers. The master controller managed operations of all controllers and the manipulator of manual control using BITBUS. It allowed both manual and automatic operation of the system.

The operating of hosting mechanism began with the information of the set position of the drum given by master computer. The whole duty cycle including acceleration, steady motion and deceleration is realized by the controller. For the experimental purposes the master controller was replaced by the outer computer.

The schema of the hoisting winch including control and measurement elements is presented in figure 9 .

To assure correct operations of the system and acquisition of interested physical parameters, the following measurement systems were installed:

- measurement system of a force in ropes $\mathrm{S}_{1}$-using strain gauge below the compensatory pulley (used also to measure a payload mass)

- measurement system of an angular speed $\omega_{\mathrm{s}}$ using encoder mounted on the rotor of the electric motor - measurement system of an angle position of the drum $\varphi_{b}$ - using absolute encoder of angular position of the shaft

Working station AWS-842TP equipped with set of measuring and control cards was used to acquisition the measured physical values and the control 


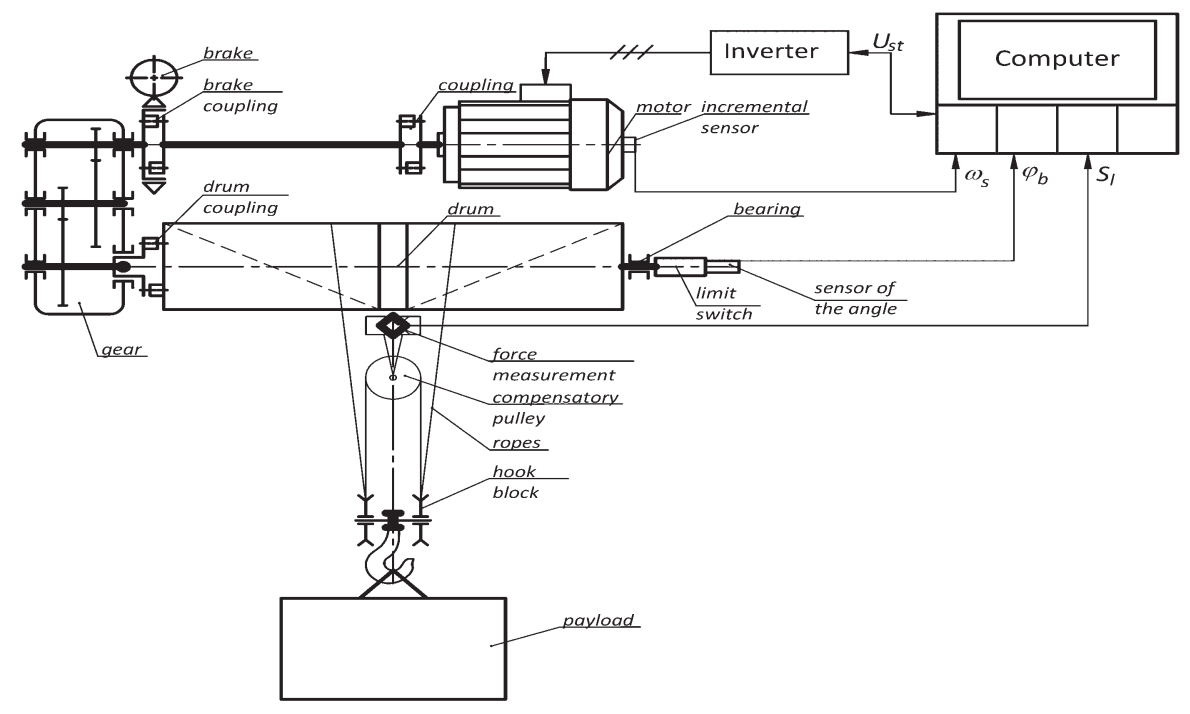

Fig. 9. The schema of the winch

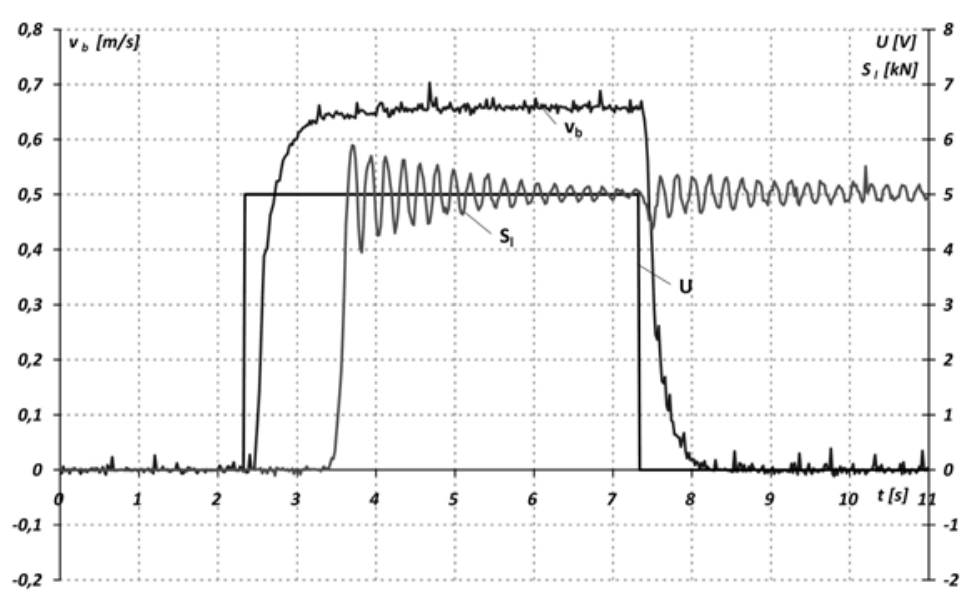

Fig. 10. The jerk of the payload without system of overloads reduction. Experimental tests

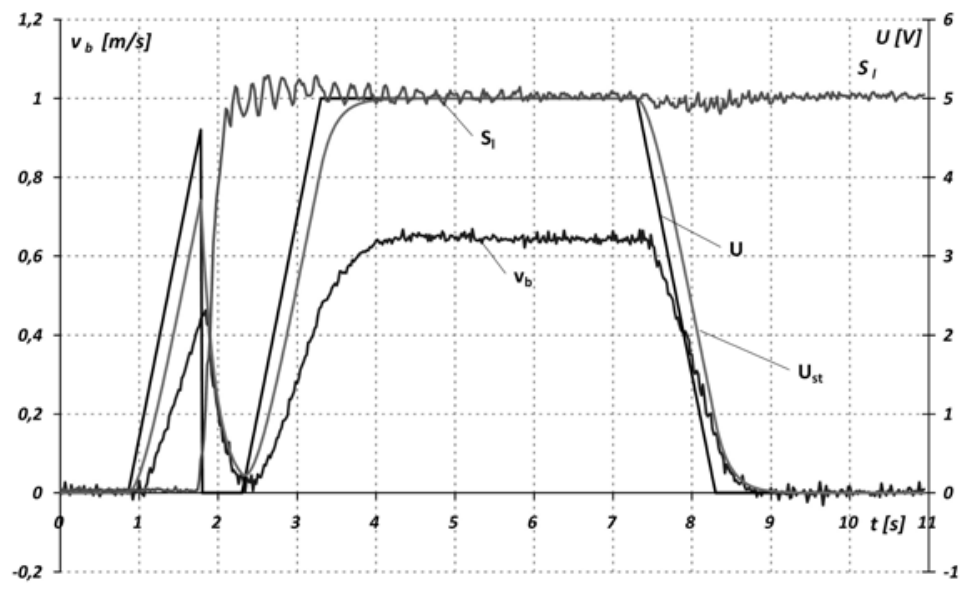

\section{The experimental tests}

The exemplary wavecharts taken from the experiment are presented in figures 10 and 11 . The input signal $\mathrm{U}$, voltage signal $U_{\mathrm{st}}$ controlling inverter, force in ropes $\mathrm{S}_{1}$ and real speed of rope on drum $\mathrm{v}_{\mathrm{b}}$ taken from changes of the angle position of the drum $\varphi_{b}$ are presented. The case of jerk of the payload without system of overloads reduction is shown in figure 10. The input signal is step signal. The payload weighed $500 \mathrm{~kg}$.

The ropes tensing began more than $2 \mathrm{~s}$ after motor start-up, when motor rotates with speed close to synchronous. It results with the overload on the level more than $26 \%$ above the steady values.

Figure 11 shows wavecharts when system of overload reduction was operated in the mode of maximum speed start-up with constant power regulator. It shows that during start-up there appeared the small oscillation of the force in ropes, which slightly exceeding the steady values. Registered overloads were under $5 \%$.

\section{Summary}

The tests of hoisting mechanism fed by inverter confirmed the correctness of operation of the control system, which was operated in the mode of maximum speed start-up with constant power regulator. Both simulation and experimental tests showed reduction of the overload from more than $25 \%$ to about $5 \%$. It gives $80 \%$ reduction of the overload above the steady values. Operation of the reduction system did not influenced on steady values of speed of the ropes. The system can be used both in automatic and manual mode of control. The parameters which are responsible for proper drive operation eg. level of force measurement sensitivity were defined.

Fig. 11. The jerk of the payload with system of overloads reduction. Experimental tests

\section{References}

1. Bogdevièius M, Vika A. Investigation of The Dynamics of an Overhead Crane Lifting Process in a Vertical Plane. TRANSPORT 2005; XX (5): 176-180.

2. Bednarski S, Cink J, Malenta P. Pozycjonowanie ładunku w ruchu roboczym wciągarki bębnowej z napędem falownikowym. Materiały IV Konferencji Okrętownictwo i Oceanotechnika. Szczecin 1998: 15-24. 
3. Eihab M, Abdel-Rahman, Ali H. Nayfeh, Ziyad N. Masoud. Dynamice and Control of Cranes: A Review. Journal of Vibration and Control 2003; 9: 863-908, http://dx.doi.org/10.1177/1077546303009007007.

4. Gašić V, Nenad Zrnić N, Obradović A, Bošnjak S. Consideration of Moving Oscillator Problem in Dynamic Responses of Bridge Cranes. FME Transactions 2011; 39: 17-24.

5. Grabowski E, Morawski A. Nowoczesne napędy falownikowe dźwignic. Transport Przemysłowy 2001; 1 (11): 33-37.

6. Grudziecki J, Malenta P, Uciński J. Zmniejszanie obciążeń dynamicznych w elementach mechanizmu podnoszenia. Problemy Maszyn Roboczych 2001; 18: 33-40

7. Haniszewski T. Hybrid analysis of vibration of the overhead travelling crane. Transport Problems 2014; 9 (2): 89-100.

8. Kosucki A. Badanie transportu ładunków przy wykorzystaniu skojarzonych ruchów mechanizmów suwnic pomostowych. Łódź: z. 474 (1175), 2013.

9. Krukowski J, Maczyński A, Szczotka M. The Influence of a Shock Absorber on Dynamics of an Offshore Pedestal Crane. Journal Of Theoretical And Applied Mechanics 2012; 50, 4 (2012): 953-966.

10. Margielewicz J, Haniszewski T, Gąska D, Pypno C. Badania modelowe mechanizmów podnoszenia suwnic. Polska Akademia Nauk. Katowice: 2013.

11. Matyja T, Sładkowski A. Modelling of the lift crane vibration caused by the lifting loads. International Conference Zdvihací Zařízení v Teorii a Praxi. Brno 2007: 98-105.

12. Michałowski S, Cichocki W. The Peak Dynamic Loading of a Winch in Term of the Rope Flexibility. Key Engineering Materials 2013; 542: 105-117, http://dx.doi.org/10.4028/www.scientific.net/KEM.542.105.

13. Newton I. Mathematical Principles of Natural Philosophy. NY: 1846.

14. Solazzi L, Incerti G, Petrogalli C. Estimation of the dynamic effect in the lifting operations of a boom crane. Proceedings 28th European Conference on Modelling and Simulation, 2014, http://dx.doi.org/10.7148/2014-0309.

15. Sun G., Kleeberger M, Liu J. Complete dynamic calculation of lattice mobile crane during hoisting motion. Mechanism and Machine Theory 2005; 40: 447-466, http://dx.doi.org/10.1016/j.mechmachtheory.2004.07.014.

16. Zrnić N, Gašić V, Bošnjak S, Dordević M. Moving Loads in Structural Dynamics of Cranes: Bridging the Gap Between Theoretical and Practical Researches. FME Transactions 2013; 41: 291-297.

\section{Andrzej KOSUCK \\ Piotr MALENTA}

Lodz University of Technology

Department of Vehicles and Fundamentals of Machine Design

ul. Żeromskiego 116, 90-924 Łódź, Poland

E-mails: andrzej.kosucki@p.lodz.pl, piotr.malenta@p.lodz.pl 